УДК 378.147: 316.422

DOI:

Свгенія Гончарова, кандидат педагогічних наук, викладач кафедри іноземних мов з латинською мовою та медичною термінологією Полтавського державного медичного університету

Олена Бєляєва, кандидат педагогічних наук, доиент, завідувач кафедри іноземних мов з латинською мовою та медичною термінологією Полтавського державного медичного університету

\title{
ЗАСТОСУВАННЯ ІННОВАЦЙНИХ ЗАСОБІВ НАВЧАННЯ В УМОВАХ СЬОГОДЕННЯ
}

У статті розглядається проблема оптимальної організачії освітнього процесу, спрямованого на підготовку фахівиів, мотиваційно-орієнтованих на безперервний процес активної пізнавальної діяльності. Аргументується закономірність комплексного застосування традиційних та інноваційних засобів навчання 3 метою отримання якісних змін у засвоєнні навчального матеріалу студентами, формуванні їх фахових компетентностей та стимулюванні пізнавальної активності.

Аналізується місие особистості викладача у процесі творчого поєднання традиційних та інноваційних засобів навчання з метою модернізації й інтенсифікації навчального процесу у сучасних $3 В О$ Украӥни.

Ключові слова: засоби навчання; пізнавальна активність; інноваційна діяльність; професійно-ціннісна інформація.

תim. 11.

Yevheniya Honcharova, Ph.D.(Pedagogy), Lecturer of the Foreign Languages with Latin and Medical Terminology Department

Poltava State Medical University

Olena Bieliaieva, Ph.D.(Pedagogy), Associate Professor, Head of the Foreign Languages with Latin and Medical Terminology Department Poltava State Medical University

\section{CURRENT USE OF THE ADVANCED TEACHING AIDS IN THE ACADEMIC PROCESS}

The article considers the problem of optimal organization of the academic process aimed at training professionals motivated to continuous process of active cognitive activity. The pattern of integrated use of traditional and advanced teaching aids to obtain qualitative changes in the acquisition of learning material by the students, the formation of their professional competencies and stimulation of cognitive activity has been discussed.

The role of the teacher's personality in the process of creative combination of traditional and advanced teaching aids aimed at modernization and intensification of the educational process in the modern HEIs of Ukraine has been analyzed. It has been determined that the basis for the effectiveness of innovative activities of educators at HEIs should be both the level of expertise and experience, readiness for self-improvement, ability to flexibly adapt to current socio-historical conditions, adequate perception of the need for the state-of-the-art innovations for further successful modernization of the academic process. Based on the analysis of the recent research works by domestic scientists, the feasibility of integrated use of the advanced teaching aids in current conditions of informatization of the society to obtain qualitative changes in the aquisition of learning material by students and the formation of their professional competencies has been proved. The system of classification of teaching aids has been proposed. The ways of implementation of the creative potential of the teacher's personality as a motive power capable of consistent actions focused on the improvement and modernization of the educational process have been analyzed. It has been shown that educators are tending to adjust their approaches to the academic process to qualitatively select modern teaching aids that will provide students with the advanced methods of cognition and increase their level of information awareness. It has been asserted that in the dynamic development of the modern society, the successful implementation of innovation-oriented pedagogical activities of the educator should be a fundamental factor in the formation of psychological readiness of students to use the state-of-the-art information and communication technologies and the formation of their information culture.

Keywords: teaching aids; cognitive activity; innovation; profession-oriented information.

П остановка проблеми. Проблема оптимальної організації навчального процесу, спрямованого на підготовку фахівців, мотиваційно орієнтованих на безперервний процес активної пізнавальної діяльності, завжди була першочерговою для викладачів закладів вищої освіти усього світу. Застосування традиційних та інноваційних засобів навчання з метою інтенсифікації засвоєння знань здобувачами вищої освіти усебічно досліджувалося 


\section{ЗАСТОСУВАННЯ ІННОВАЦЙНИХ ЗАСОБІВ НАВЧАННЯ В УМОВАХ СЬОГОДЕННЯ}

як зарубіжними, так і вітчизняними науковцями.

В останні роки викладачі ЗВО України значну увагу приділяли упровадженню в освітній процес інформаційно-комунікаційних технологій як інноваційного засобу навчання, що має реальні передумови для плідного використання у процесі навчання. У практичній діяльності потенційні можливості інноваційних засобів навчання викладачами спрямовувалися як на забезпечення здобувачів вищої освіти необхідним обсягом професійно-значущих знань, так і на підвищення рівня їх інформаційної культури, ознайомлення 3 сьогочасними методами пізнання.

Аналіз останніх досліджень та публікацій. Дослідженню проблеми упровадження у навчальний процес традиційних та інноваційних засобів навчання присвячено роботи О. Арбузової [1], В. Бикова [3], І. Малафіїка [6, 7], О. Малихіна [8] Т. Туркот [11] та інших. За визначенням О. Арбузової, саме доцільне використання засобів навчання гарантує реалізацію дидактичного принципу наочності, який вважається “золотим правилом дидактики” [1, 27], I. Малафіїк стверджує, що засоби навчання як “елемент дидактичної системи, який відповідає на запитання "Чим, за допомогою чого вчити?”, допомагає учителеві виділити і пред'явити для засвоєння предмет вивчення" [7, 355].

Мета статті: на підгрунті аналізу останніх досліджень вітчизняних та зарубіжних науковців аргументувати закономірність комплексного застосування традиційних та інноваційних засобів навчання 3 метою отримання якісних змін у засвоєнні навчального матеріалу здобувачами вищої освіти, формуванні їх фахових компетентностей та стимулюванні пізнавальної активності.

Виклад основного матеріалу. На тлі бурхливих соціально-економічних перетворень сучасного суспільства освітні інновації розглядаються як “комплексний, цілеспрямований процес втілення, засвоєння, використання та поширення в освітній діяльності нових ідей, порядків, звичаїв, методів, прийомів, технологій, механізмів, систем, структур, явищ тощо” [5, 131], стратегічно спрямований на оптимальну трансформацію системи вищої освіти в Україні 3 метою повсякчасного підвищення рівня 111 ефективності та, одночасно, забезпечення стабільності їі функціонування.

В епіцентрі процесу втілення у навчальний процес освітніх інновацій завжди залишається творча особистість викладача. Саме вона $\epsilon$ рушійною силою, здатною на послідовні дії, зорієнтовані на поліпшення та осучаснення навчального процесу. Базисом результативності інноваційної діяльності викладачів закладів вищої освіти має бути не тільки рівень кваліфікації та досвіду, але й готовність до самовдосконалення, здатність гнучко адаптуватися до сучасних суспільно-історичних умов, адекватне сприйняття необхідності упровадження актуальних нововведень задля подальшої успішної модернізації освітнього процесу. Узагальнення та аналіз педагогічного досвіду доводять значимість застосування засобів навчання як у ході репродуктивної навчальної діяльності, так і у дослідницькопізнавальних діях здобувачів вищої освіти.

Наведені нижче формулювання науковців визначають засоби навчання як дієвий інструмент для оптимального досягнення дидактичних цілей навчання:

- засоби навчання - це джерело отримання знань, формування вмінь [4, 122].

- засоби для оптимізації викладання та навчання [9, 293];

- засоби, що дають змогу описати об'єкт вивчення або одержати його замінник (модель), виділити предмет вивчення та пред'явити його для засвоєння [6, 250];

Свою систему класифікації засобів навчання пропонує В. Биков:

Окремі засоби навчання, або просто засоби навчання - це матеріальні об'єкти (елементи) навчального середовища, які призначені для використання учасниками освітнього процесу при здійсненні ними окремих навчальних дій.

Комплекти засобів навчання - структурно упорядковані сукупності засобів навчання, які призначені для забезпечення навчальної діяльності за однією структурою.

Комплекс засобів навчання - структурно упорядкована сукупність засобів навчання, яка призначена для забезпечення навчальної діяльності за декількома структурами.

Система засобів навчання - підсистема навчального середовища, склад якої утворюють інтегровані засоби навчання, а структура визначається множиною навчальних цілей їх використання учасниками освітнього процесу $[3,184]$.

Адекватна оцінка місця і значення кожного окремого засобу навчання у загальній структурі навчального процесу дає змогу повноцінно використовувати їх вплив на продуктивність засвоєння загальнонаукових та професійнозначущих знань здобувачами вищої освіти.

Стратегічний підхід до запровадження i подальшого використання традиційних та інноваційних засобів навчання має бути 
комплексним та зваженим. Спираючись на узагальнення свого педагогічного досвіду та аналіз досліджень вітчизняних і зарубіжних науковців, викладач інтегрує у навчальному процесі усі наявні різновиди засобів навчання так, щоб кожен із них доповнював інший.

Маючи на меті стимулювання діяльніснокомунікативної активності студентів та продуктивності їх запам'ятовування, викладачі зазвичай на основі системного аналізу та грунтовно спланованого добору, застосовують у навчальному процесі як традиційні, так і інноваційні засоби навчання, що відповідають поставленим дидактичним цілям [2]. Зважаючи на стрімкий розвиток сучасних технологій, їх упровадження та поширення, проблема інноваційних змін в освітній системі обумовлює тенденцію коригування викладачами підходів до навчального процесу з метою якісного добору саме тих сучасних засобів навчання, які забезпечать ознайомлення здобувачів вищої освіти з новітніми методами пізнання і підвищать рівень ї інформаційної обізнаності та інформаційної культури. "Сьогодні надії щодо ефективності та продуктивності організації навчальної праці пов'язуються з використанням і впровадженням в освітній процес інформаційних технологій” $[8,201]$. Ефективне упровадження у процесі навчання досягнень інформаційних та комп'ютерних технологій надає допомогу здобувачам вищої освіти у засвоєнні та сприйнятті значних обсягів навчального матеріалу, розвиває здатність упевнено орієнтуватися в інформаційному просторі [2]. “Сучасний навчальний процес важко уявити без їх (сучасних засобів навчання) застосування, оскільки вони дають можливість показати динаміку, рух, зміну, процес перебігу явища вивчення, виділити предмет вивчення і пред'явити його для засвоєння" [7, 359], а конкретно комп'ютер, використовуваний як засіб навчання, відрізняється тим, що “дає можливість вести своєрідний діалог “учень-комп’ютер”, що є безцінним в організації та сприйманні навчальної інформації та здійсненні контролю і оцінювання знань" [7, 359].

Використання інноваційних засобів навчання на сучасному етапі соціально-економічних змін у незалежній Україні орієнтується на усебічну грунтовну підготовкуплеяди конкурентоспроможних, здатних до творчої самоосвіти та використання отриманих знань у подальшій практичній діяльності фахівців. “Основна стратегія навчання повинна складатися, таким чином, у створенні психолого-педагогічних умов стимулювання інтелектуальної активності й ініціативи, самостійності мислення під час здійснення усіх видів навчальної діяльності" [8, 201].

Застосування нововведень в освітньому просторі спрямовується на модернізацію організації навчального процесу, його адаптацію до сучасних реалій соціально-економічних трансформацій, потреб сьогоденного суспільного буття і розглядається сучасними українськими науковцями в аспекті стимулювання пізнавальної активності студентів, формування і розвитку їх навичок самостійної навчальної діяльності, уміння орієнтуватися в останніх здобутках сучасної науки та здатності до системного пошуку, опрацювання і використання професійно-ціннісної інформації.

Використання сучасних інформаційних технологій набуває особливої значущості з точки зору “не лише засвоєння визначеного навчальною програмою обсягу знань, але й опанування методом добування нових знань" [7, 360], “формування вмінь самостійно здійснювати пізнавальну й навчальну діяльність” [8, 201]. Як показує практика, оптимальне поєднання у педагогічній діяльності викладачів закладів вищої освіти новітніх інформаційних технологій та традиційних засобів навчання допомагає досягти якісної організації навчальної діяльності здобувачів вищої освіти, сприяє становленню та розвитку їх пізнавальної активності, результативність якої “виявляється в знаннях, отриманих особистістю, у тих змінах у системі поглядів, переконань, учинків, які відбуваються в людині завдяки розвитку його пізнавальної діяльності" $[10,223]$.

До останнього часу функціональні можливості інформаційно-комунікаційних технологій досить широко використовувалися 3 метою пошуку додаткових джерел інформації, в організації активного діалогу викладача зі здобувачами вищої освіти, у налагодженні діалогічної взаємодії здобувачів вищої освіти тощо. Цей засіб навчання вважався багатообіцяючим у майбутньому, але у розв'язанні поточних проблем виконував тільки допоміжну роль. Перехід на дистанційну форму навчання, пов'язаний з епідемією COVID-19, змусив переглянути статус інноваційних засобів навчання у загальній ієрархії засобів навчання.

Упровадження нововведень у навчальний процес не означає відмови від традиційних засобів навчання, таких, як підручник чи виклад нового матеріалу викладачем, а також засобів наочності - натуральних (реальні предмети, явища, процеси i т. ін.), зображувальних (картини, муляжі), знаково-символічних (схеми, графіки, діаграми) [7, 358].

Підручник - це “особлива дидактична 


\section{ЗАСТОСУВАННЯ ІННОВАЦЙНИХЗАСОБІВ НАВЧАННЯ В УМОВАХ СЬОГОДЕННЯ}

система, яка розкриває зміст навчання, що передбачається навчальною програмою” [7, 355], “ядро системи засобів навчання" [7, 356], він “повинен виконувати функцію “проекту” процесу навчання” [7, 357]. Підручник доповнюють такі засоби навчання, як довідники, словники, посібники, засоби візуалізації, що поглиблюють та конкретизують інформацію, отриману при опрацюванні підручника. Т. Туркот зазначає, що читання навчальних текстів забезпечує $10 \%$ засвоєння, а використання відео та аудіоматеріалів $-20 \%[11,287]$.

За переконанням I. Малафіїка, слово вчителя $\epsilon$ винятково значущим засобом навчання. “Слово учителя можна поставити в один ряд із підручником за системоутворюючим значенням системи засобів навчання" [7, 357].

Виняткова значущість слова вчителя полягає у спроможності “крім інформаційної і комунікативної функції виконувати ще й функцію організаційну” [7, 357]. Сутність останньої полягає у можливості цілеспрямованого використання педагогічного впливу задля формування уявлень і переконань суб'єктів навчання, організації їх мисленнєвих процесів, розвитку емоцій і почуттів [7].

Комунікативна діяльність викладача зосереджується на організації дієвої суб'єктсуб'єктної взаємодії зі здобувачами вищої освіти. Вищевказані відносини вибудовуються на засадах взаєморозуміння, емпатії та довіри і допомагають сформувати сприятливе педагогічне середовище, надають змогу викладачеві визначати, аналізувати й оцінювати особисті інтелектуальні, поведінкові, мотиваційні якості суб'єктів навчання 3 метою знаходження оптимальних рішень стосовно способу спілкування з кожним індивідом у подальшому процесі навчання.

Слово викладача розкриває суть нового навчального матеріалу, акцентує увагу на ключових моментах теми, що розглядається, створює позитивну мотивацію стосовно подальшої роботи з підручниками та посібниками. T. Туркот, посилаючись на дослідження американських та європейських науковців, відзначає, що прослухана лекція забезпечує лише близько $5 \%$ засвоєння, [11, 287]. Однак саме вищевказані 5 \% становлять основу для подальшого грунтовного осмислення i формування нових знань, умінь та навичок.

Аналіз показує, що успішне розв'язання проблем навчання, розкриття його змісту і цілей можливе тільки у процесі інтеграційного використання усіх функцій, притаманних слову викладача

Сучасний здобувач вищої освіти зазвичай ще до вступу до ЗВО, володіє основами користування комп'ютерною технікою, впевнено орієнтується у можливостях інтернету. Завдання викладача полягає у роз'ясненні майбутнім фахівцям перспектив та потенційних шляхів застосування інформаційно-технологічних засобів навчання з метою інтенсифікації засвоєння нового навчального матеріалу, успішного виконання самостійної роботи, отримання професійнозначущої інформації, що повсякденно оновлюється.

Творчо використовуючи здатність інформаційнотехнологічних засобів навчання, надавати безмежний обсяг інформації, викладач отримує можливість ініціювати та культивувати фахову спрямованості навчально-пізнавальної діяльності здобувачів вищої освіти, завдяки чому закладає основу формування їх фахових компетентностей.

Висновки. Узагальнюючи вищевказане, можемо зробити висновок, що в умовах динамічного розвитку сучасного суспільства, успішна реалізація інноваційної спрямованості педагогічної діяльності викладача має стати основоположним фактором становлення психологічної готовності суб'єктів навчання до використання сучасних інформаційно-комунікаційних технологій та формування їх інформаційної культури. Раціональне застосування традиційних та інноваційних засобів навчання вважаємо невід'ємною складовою загальної системи модернізації вищої освіти в Україні.

\section{ЛIТЕРАТУРА}

1. АрбузоваЕ. Н., Усольцева Л. В. Конструирование и применение комплексов средств обучения для методической подготовки студентов-биологов в условиях информационно-предметной среды вуза. Омск, 2010. 162 c.

2. Бєляєва О. М., Гончарова Є. С. Роль традиційних та інноваційних засобів навчання в модернізації вищої освіти. Актуальні питання лінгвістики, професійної лівнгводидактики, психології $i$ педагогіки вищої школи: матер. IV міжнар. наук.-практичної конф.: (м. Полтава, 7-8 листопада 2019 року). Полтава, 2019. С. 18-21.

3. Биков В. Ю. Теоретико-методологічні засади створення і розвитку сучасних засобів та е-технологій навчання. Збірник наукових праць до 10-річчя АПН України / Академія педагогічних наук України. Ч. 2. Харків, 2002. С. 182-189.

4. Воронов В. В. Педагогика школы в двух словах. Москва, 2002. 144 с.

5. Гончар Л. Інновації у формуванні професійної культури майбутніх менеджерів. Молодь і ринок. 2019. № 10 (177). С. 130-134. 
6. Малафіїк I. В. Дидактика : навчальний посібник. Київ, 2005. 397 с.

7. Малафіїк І. В. Дидактика новітньої школи : навчальний посібник. Київ, 2014. 632 с.

8. Малихін О. В. Організація самостійної навчальної діяльності студентів вищих педагогічних навчальних закладів: теоретикометодологічний аспект : монографія. Кривий Ріг, 2009. 307 c.

9. Оконь Винценты Введение в общую дидактику; пер. с пол. Л. Г. Кашкуревич, Н. Г. Горин. Москва, 1990. 382 с.

10. Ситаров В. А. Дидактика: учеб. пособие для студ. высш. пед. учеб. заведений. Москва, 2004. 368 с.

11. Туркот Т. I. Педагогіка вищої школи : навчальний посібник для студентів вищих навчальних закладів. Київ, 2011. 628 с.

\section{REFERENCES}

1. Arbuzova, Ye. N. \& Usoltseva, L. V. (2010). Konstruirovanie i primenenie kompleksov sredstv obucheniya dlya metodicheskoy podgotovki studentov-biologov v usloviyakh informatsionnopredmetnoy sredy vuza [Design and use of complexes of teaching aids for the methodological training of biology students in the information-subject environment of the university]. Omsk, $162 \mathrm{p}$. [in Russian].

2. Bieliaieva, O. M. \& Honcharova, Ye. Ye. (2019). Rol tradytsiinykh ta innovatsiinykh zasobiv navchannia $v$ modernizatsii vyshchoi osvity [The role of traditional and innovative teaching aids in the modernization of higher education]. Aktualni pytannia linhvistyky, profesiinoi livnhvodydaktyky, psykholohii i pedahohiky vyshchoi shkoly: mater. IV mizhnar. nauk.-praktychnoi konf. : (m. Poltava, 7-8 lystopada 2019 roku). - Current issues of linguistics, professional language didactics, psychology and pedagogy of higher education: Proceedings of the IV International Scientific-Practical Conference : (Poltava, November 7-8, 2019). Poltava, pp. 18-21. [in Ukrainian].

3. Bykov, V. Yu. (2002). Teoretyko-metodolohichni zasady stvorennia i rozvytku suchasnykh zasobiv ta e-tekhnolohii navchannia [The theoretical and methodological principles of creation and development of modern tools and e-technologies of teaching]. Collection of scientific works to the 10th anniversary of the Academy of Pedagogical Sciences of Ukraine / Academy of Pedagogical Sciences of Ukraine. Part. 2. Kharkiv, pp. 182-189. [in Ukrainian].

4. Voronov, V. V. (2002). Pedagogika shkoly v dvukh slovakh [School pedagogy in a nutshell]. Moscov, 144 p. [in Russian].

5. Honchar, L. (2019). Innovatsii u formuvanni profesiinoi kultury maibutnikh menedzheriv [Innovations in the formation of professional culture of future managers]. Youth \& market. No. 10 (177). pp. 130-134. [in Ukrainian].

6. Malafiik, I. V. (2005). Dydaktyka : navchalnyi posibnyk [Didactics: a textbook]. Kyiv, 397 p. [in Ukrainian].

7. Malafiik, I. V. (2014). Dydaktyka novitnoi shkoly : navchalnyi posibnyk [Didactics of the newest school: a textbook]. Kyiv, 632 p. [in Ukrainian].

8. Malykhin, O. V. (2009). Orhanizatsiia samostiinoi navchalnoi diialnosti studentiv vyshchykh pedahohichnykh navchalnykh zakladiv: teoretykometodolohichnyi aspekt : monohrafiia [An organization of independent educational activity of students of higher pedagogical educational institutions: theoretical and methodological aspect: monograph]. Kryvyi Rih, 307 p. [in Ukrainian].

9. Okon Vintsenty (1990). Vvedenie v obshchuyu didaktiku [Introduction to general didactics]. Translation from Polish L. G. Kashkurevich, N. G. Gorin. Moscov, 382 p. [in Russian].

10. Sitarov, V. A. (2004). Didaktika: ucheb. posobie dlya stud. vyssh. ped. ucheb. Zavedeniy [Didactics: textbook. manual for stud. higher. ped. study. Establishments]. Moscov, 368 p. [in Russian].

11. Turkot, T. I. (2011). Pedahohika vyshchoi shkoly: navchalnyi posibnyk dlia studentiv vyshchykh navchalnykh zakladiv [Higher school pedagogy: a textbook for students of higher educational institutions]. Kyiv, 628 p. [in Ukrainian].

Стаття надійшла до редакції 07.07.2021

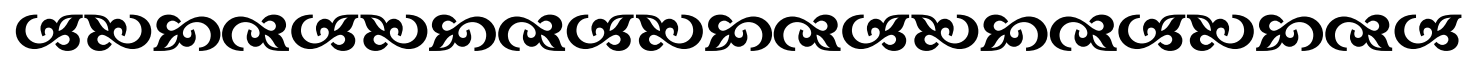

"Найскладніше почати діяти, все інше залежить тільки від наполегливості". Амелія Ергарт америқансьқа авіаторка

\section{G5808020580}

